\title{
A cost benefit model for high capacity transport in a comprehensive line-haul network
}

\author{
David Lindqvist, Marwan Salman and Rickard Bergqvist ${ }^{*}$
}

\begin{abstract}
The objective of the paper is to analyse the potential of introducing High Capacity Transport (HCT) within a comprehensive line-haul network. Barriers and enablers have been identified, and a cost benefit model has been developed. The model considers environmental performance, socio-economic costs and operational costs and has been applied to a Swedish context and case study. The findings reveal that HCT can contribute to the development of road transportation in the perspectives of energy consumption and emission releases. It can further strengthen the trade and competitiveness of Swedish hauliers, as the introduction can provide a more cost-efficient system for all actors, including the transporter. However, the potential is largest when longer vehicles are meticulously and scrupulously introduced on a designated network alone.
\end{abstract}

Keywords: Road haulage, High capacity vehicles, Transport energy consumption, Freight transportation performance, Longer vehicles, Cost benefit analysis

\section{Introduction}

Road freight transport is currently the dominant mode of transport in many countries, including Sweden. Continued growth in road freight transport is further expected in many regions, and a large part has derived from the trend of e-commerce. This development is equivalent to an increase in the total number of driven tonne- $\mathrm{km}$ and vehicle- $\mathrm{km}$ linked to the transportation of goods [1], which brings consequences that will impact society, the economy and the environment.

Nearly half of the released $\mathrm{CO}_{2}$ emissions in Sweden are derived from the transportation sector, for which road transport covers almost 93\% [2]. The Swedish government office has defined a climate target to reach the goal of zero emissions of greenhouse gases [3, 4]. Therefore, there is an urgent need for innovation regarding new approaches for conducting road freight. By

\footnotetext{
* Correspondence: rickard.bergqvist@handels.gu.se

Industrial and Financial Management and Logistics, Department of Business

Administration School of Business, Economics and Law at University of Gothenburg, P.O. Box 610, SE 40530 Göteborg, Sweden
}

increasing the maximum permitted weight and/or length of the trucks used to transport goods, there is potential to reduce negative aspects. The possibilities of High Capacity Transport (HCT) is an efficient practice to achieve a higher capacity in the road transportation network. The increased capacity will enable more weight and/or volume of goods to be loaded onto the trucks. The cost of transportation per unit of carried goods will be reduced along with the quantity of emissions and improved road safety, as fewer trucks are required [5]. This drive positive effects on transport costs and the environmental impact from the transport sector $[6,7]$.

HCVs release more emissions than conventional vehicles due to a higher consumption of fuel and energy needed; therefore, they also become more expensive per vehicle-km [8, 9]. Nevertheless, as loading capacity is greater in $\mathrm{HCVs}$, fewer vehicles are needed to freight the same amount of goods that otherwise would have been transported by conventional vehicles. HCVs are, therefore, reducing total fuel and energy consumption, emissions and $\mathrm{CO}_{2}$ per tonne-km [9-12]. The activities in a

\section{Springer Open}

(๑) The Author(s). 2020 Open Access This article is licensed under a Creative Commons Attribution 4.0 International License, which permits use, sharing, adaptation, distribution and reproduction in any medium or format, as long as you give appropriate credit to the original author(s) and the source, provide a link to the Creative Commons licence, and indicate if changes were made. The images or other third party material in this article are included in the article's Creative Commons licence, unless indicated otherwise in a credit line to the material. If material is not included in the article's Creative Commons licence and your intended use is not permitted by statutory regulation or exceeds the permitted use, you will need to obtain permission directly from the copyright holder. To view a copy of this licence, visit http://creativecommons.org/licenses/by/4.0/. 
transport chain can evoke negative effects such as congestion, accidents, noise, infrastructure wear and tear, air pollution and other environmental impacts [13]. These effects are elements that form external costs. One way of reducing emissions is to explore the possibilities with $\mathrm{HCT}$ as a solution from a socio-economic and environmental perspective [6]. Strict requirements for permission to use HCVs, increased carefulness when driving larger and heavier vehicles, and driving on larger and safer roads while utilising greater safety equipment are also possible factors for a reduced risk and, thus, increased safety for the largest vehicles, resulting in decreased accident costs in total [7, 14-18]. It can also be seen that the largest vehicles in Alberta, Canada, have a $58 \%$ lower risk for accidents than standard semi-trailer combinations [19]. Similar findings have been presented in a more recent study analysing the safety of HCT traffic in Sweden and further claims that longer vehicles tend to be safer with less risk for accidents [18, 20-22], independent of any modal shift traffic safety increase due to fewer trucks in traffic [23]. Finland which has been permitting heavier HCVs since 2013 and longer HCVs since 2019, has only reported positive experiences concerning road safety. The interactions with tunnels, bridges and roads (e.g. road crossings, roundabouts, country roads with high accidental risks or highways with high intensity of traffic) must also be considered even if the physical infrastructure is affected little when implementing longer vehicles as longer vehicles contain more axles and the load can be more evenly distributed and the load per axle decreases [24, 25]. However, the impact on infrastructure depends on the national standards and may vary between countries. Nevertheless, However, the financial impact is the most important factor for the transporters. Knight et al. [6] compared the operating costs of different vehicle types, clearly showing that HCVs have the lowest operating cost per tonne-km. However, these calculations have been made on the assumption of $100 \%$ payload and utilisation. The fill rate and utilisation of long and heavy vehicles (LHVs) and HCVs are an important factor that is simultaneously a challenge for many hauliers. It is hard to realise an average fill rate above $70 \%$ [26], because flexibility must be ensured to handle fluctuations in demand [27]. As more goods are transported in one vehicle, the various costs related to the vehicle are levelled out over a larger quantity of carried goods. Previous studies have shown that the cost per tonne- $\mathrm{km}$ is reduced by $20-33 \%$ and fuel consumption by $25-35 \%$ when HCVs longer than $26 \mathrm{~m}$ are used [19].

In recent years, several HCT programmes have been carried out in Sweden by, among others, Closer, Swedish Transport Agency, Swedish Transport Administration, Transport Research Institute (VTI), Vinnova and Trivector.
These have focused on the positive and negative effects of introducing High Capacity Vehicles (HCVs) on Swedish roads. HCT pilot case studies have been conducted in, for example, the ETT project [28], Duo2 project [24], One Coil More [29] and the case of Jula [30].

There are diverse attitudes and points of view found among different stakeholders regarding HCT. Those who favour the use of HCVs claim it will contribute to an increased transport efficiency per tonne- $\mathrm{km}$ with reduced operational costs for hauliers as well as environmental impacts. Those who disagree claim that a potential increase in transport efficiency will be neglected because of a greater demand for transport, a modal shift to road transport and needed infrastructure investments from society [31]. Historically, the result from permitting larger vehicles in Sweden to $25 \mathrm{~m}$ has however been positive in terms of social benefits and other externalities, as it has resulted in fewer vehicle-km per given amount of tonne- $\mathrm{km}$ [32]. Furthermore, if pre- and post-haulage were to be performed by HCVs rather than the standard haulage setup, there would be potential to decrease the total costs for intermodal transport for the shippers by $10 \%$ when the haulage accounts for about $20 \%$ of the total costs of the transport chain. This change has the potential to create a substantial modal shift, as the break-even point is relocated, and intermodal rail-road transport becomes more competitive. If regulations for HCT were more generous regarding vehicle length, this could contribute to better cost efficiency for intermodal transport by addressing the problem of last mile efficiency [30,33].

\subsection{Objective}

While the benefits and risks of HCT can easily be calculated upon singular and shorter routes, there is limited research on more complex and comprehensive networks. The gross potential of using HCT also varies if the maximum weight and/or length are changed. The reason for this is that goods might have different limitations and are only affected when the capacity increases in the relevant aspect $[1,34,35]$. HCVs can, therefore, only be defined by length, weight or both. As grouped and mixed goods often are limited by volume and loading metres (LDM), in this paper, HCVs are defined as only longer vehicles and not as heavier and longer vehicles.

The objective of this paper is to develop and present a model that calculates the costs and benefits of an introduction of HCT within a comprehensive line-haul network and identify the barriers and enablers. This has been applied to the line-haul network of DHL Freight Sweden (DHL) to "provide an understanding of how benefits can be achieved with respect for different aspects that is to be viewed from a system perspective." This is vital to create an understanding of how longer 
trucks and their increased capacities affect the full system with respect to all stakeholders. The research question is defined as: What are the potential benefits and disadvantages of HCT from the perspective of operational costs, environmental performance and external costs?

\section{Method}

In recent years, DHL has experienced a rapid yet stable growth in grouped goods and packages as a result of the development of e-commerce, and the terminal in Malmö alone had an increased demand of 35\% during 2018. DHL had an average fill rate utilisation of $65 \%$, including journeys with fully empty trucks, during 2017 and $75 \%$ during 2018 and is recognising an urgent need for increased capacity [36]. The growth has been challenging due to capacity restrictions, and there is currently a high average fill rate in the haulier's fleets.

To address the research question and the objective of the report, primary data have been gathered through interviews and data retrieval from DHL's ERP system. The data contain all freight transports expressed in volumetric weight between all 25 terminals (Fig. 1) and 600 relationships during 2018 in Sweden. Secondary data were gathered through other reports and research publications. For comparison reasons, reports from Finland, the UK, Australia, the Netherlands and previous projects in Sweden have been examined. Finally, the Swedish Transport Administrations research study [37] regarding HCT in Sweden has been analysed and validated.

To provide an understanding of how HCT could influence the comprehensive line-haul network, calculations between each terminal's relationship have been studied and analysed. HCVs are defined as only longer vehicles in the calculations, as the carried goods are primarily limited by the volume. Three scenarios were then analysed. The first scenario represents the present situation in which all freight is carried by solely LHVs that are currently used and permitted, with the present costs as is. The second scenario represents freight carried with solely HCVs, which leaves the third scenario to compare the cost per transport if carried by LHVs and/or HCVs and appoint the most cost-efficient alternative. This scenario is, therefore, referred to as 'optimal' and is a mixture of both configurations revolving around the most suitable and cost-efficient alternatives.

The different scenarios are developed to illustrate transparency between the results. Only one result alone is not sufficient enough to compare the costs of LHVs with those of HCVs. There might, for example, exist a more optimal equilibrium between them. The fact that each terminal's traffic differs from day to day in relation to the demand for freight also indicates that the suggested setup of vehicles could be a combination of both
LHVs and HCVs and, thus, not just one of the two (Table 1).

\subsection{HCT cost benefit model}

The proposed model calculates the relative costs from a system perspective in which the operational costs for hauliers and the external costs for society are covered in the equations and functions of the model. The external costs are derived from the outcome of the operational premises' fuel consumption and distance between the origins and destinations and are thereafter used in combination with theoretical findings that describe the externalities in absolute numbers. To gain transparency, a sensitivity analysis approach is further applied and calculated upon as a foundation of the resulting analysis in the three scenarios.

The fundamental variables of the calculations and formulas used are hereafter explained in detail to fulfil required reliability to the developed model. Every calculation and formula are performed for each relationship and day for every terminal in the network.

The cost parameters were based primarily on Flodén [39], Asmoarp et al. [40], Adell et al. [41], Johansson and von Hofsten [42], and the Swedish Transport Administration [43]. The costs were adjusted to the financial inflation through the Sweden Statistics price calculator [44] to 2019 prices. The fixed costs were broken down per $\mathrm{km}$, and the variable costs were broken down per $\mathrm{km}$ or hour. The calculations related to operational costs were derived from DHL and are hence justified and validated. The accident costs were derived from calculations by Flodén [39] and other external costs from Adell et al. [41].

The first step was to create two formulas to break down the volumetric weight to variables that are easier to apply in the calculations. It was most logical to convert the need of capacity in volumetric weight to LDMs due to the characteristics of DHL's carried goods. To calculate the needed capacity of trucks in terms of LDMs, there must be a factor representing the weight of the goods equivalent to one LDM. This variable was used as the base in all further calculations, as this illustrated a realistic perspective of how the transportation of freight is planned and handled in the context of DHL's line-haul operations. The average weight per LDM during 2018 was based on the value of $1300 \mathrm{~kg}$.

$$
\text { Required LDMs }=\frac{\text { Volumeteric weight }}{\text { Kg per LDM }}
$$

When the volumetric weight was recalculated to LDMs, it became possible to calculate the number of vehicles needed, as the required capacity to saturate the demand for freight transport was given. The next step was to calculate the demanded vehicles needed for each relationship 


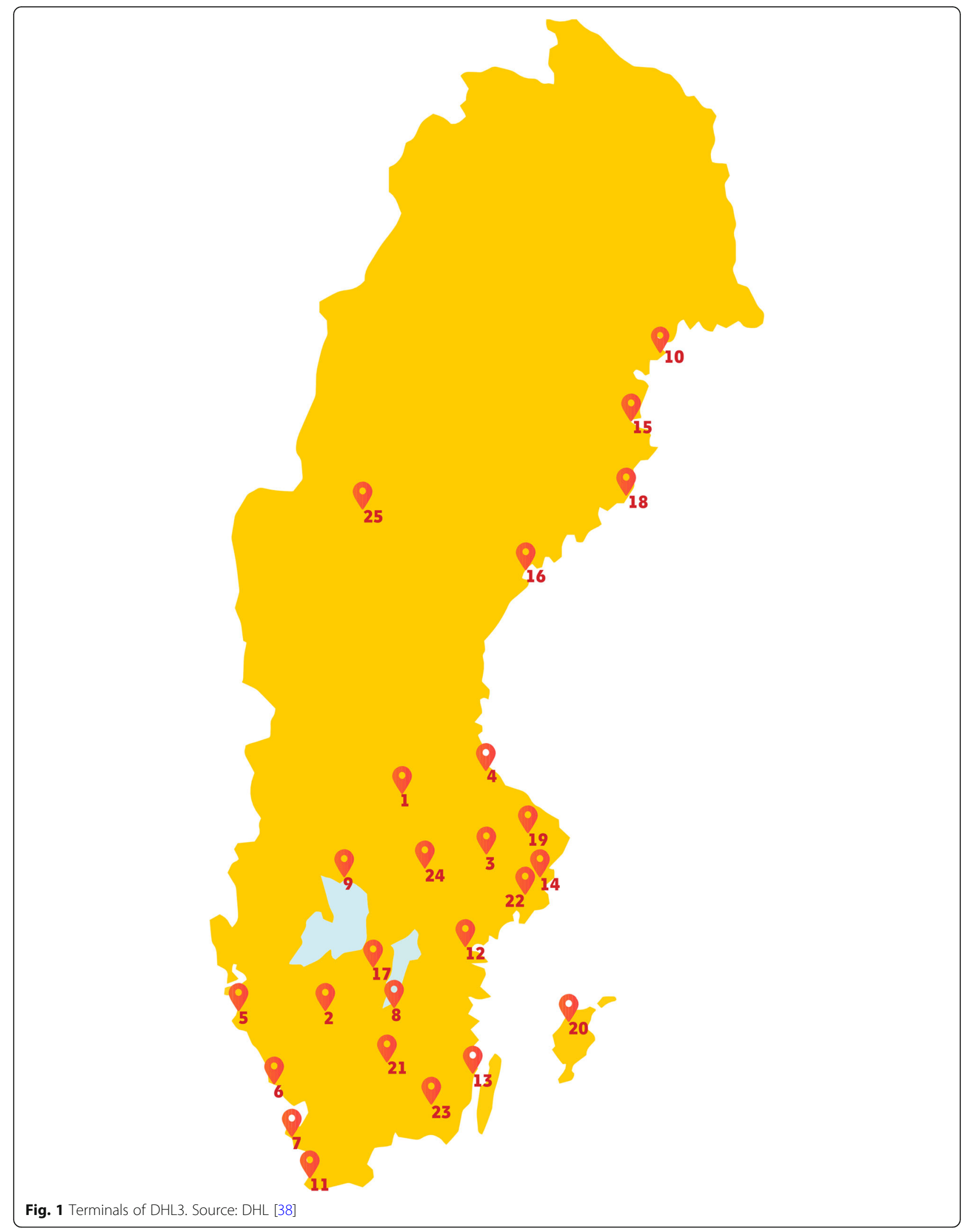


Table 1 Map of the different Scenarios

\begin{tabular}{|c|c|c|c|}
\hline & $\begin{array}{l}\text { Scenario A } \\
\text { Solely LHV }\end{array}$ & $\begin{array}{l}\text { Scenario B } \\
\text { Solely HCV }\end{array}$ & $\begin{array}{l}\text { Scenario C } \\
\text { Optimal }\end{array}$ \\
\hline Vehicle Type & LHV 64 t / 25.25 m & HCV 64 t / 34.5 m & $\begin{array}{l}\text { LHV } 64 \mathrm{t} / 25.25 \mathrm{~m} \\
\text { HCV } 64 \mathrm{t} / 34.5 \mathrm{~m}\end{array}$ \\
\hline Extent & Full Terminal Network & Full Terminal Network & $\begin{array}{l}\text { HCV only operates when it is more cost } \\
\text { efficient than LHVs }\end{array}$ \\
\hline Description & $\begin{array}{l}\text { A current situation analysis and net } \\
\text { present value in which only LHVs are } \\
\text { permitted to operate in the terminal } \\
\text { network }\end{array}$ & $\begin{array}{l}\text { A situation analysis in which HCVs } \\
\text { are introduced in the full terminal } \\
\text { network and replace all LHVs }\end{array}$ & $\begin{array}{l}\text { A situation analysis in which the vehicle } \\
\text { most optimised for every single trip } \\
\text { between two different terminals is used, } \\
\text { with respect to capacity and operational } \\
\text { costs }\end{array}$ \\
\hline
\end{tabular}

and day in the terminal network. This was calculated for both LHVs and HCVs in order to ultimately have the possibility to compare the effects of choosing either of the two. Also, the average fill rate was included in this formula to achieve a truthful output.

$$
\begin{aligned}
L H V_{N} & =\frac{\text { Daily demand } L D M s}{L H V \text { trailer length } * \text { Average fill rate }} \\
H C V_{N} & =\frac{\text { Daily demand } L D M s}{L H V \text { trailer length } * \text { Average fill rate }}
\end{aligned}
$$

This resulted in non-absolute numbers, as the demand, for example, could be 4.39 for LHV and 3.15 for HCV. These numbers had to be rounded off to the upper absolute integer value, which, in this example, would result in 5 LHVs and 4 HCVs. Therefore, a formula applied to systematically round up the numbers was added to the model.

Required vehicles in absolute numbers $=$ Roundup (Demanded vehicles; 0$)$

The upcoming step was to calculate the costs of the capacity for both vehicle types. The cost structure variables used in the model were divided into fixed costs, distance-based variable costs and time-based variable costs (see Table 2).

The result from interviews with DHL implied that the vast majority of trucks are used throughout their full lifetime which is between six to 9 years. The yearly depreciation has been calculated through a degressive depreciation method and was used as the depreciation amount equal to ((degressive $25 \% \mathrm{x}$ amount of depreciation days $\mathrm{x}$ base of depreciation) divided by $(100 \times$
360)) over 7,5 years which also resulted in a residual value of $12 \%$. The base of depreciation is equal to price of procurement subtracted with each continuous period's added value of depreciation. The costs, with aggregated fixed and variable costs (FC and VC), for each vehicle type was then calculated as:

$$
\begin{gathered}
F C_{h}=\frac{(\text { Yearly depreciation }+ \text { Cost of capital })}{\text { Utalised hours per year }} \\
V C_{k m}=\text { Tires }+ \text { Repairs }+ \text { Depreciation }+\left(\text { Fuel }_{l / k m} * \text { Fuel }_{S E K / l}\right) \\
T V C_{h}=\text { Salary }+ \text { Other }+\left(\text { VC }_{k m} * \text { Average speed }_{k m / h}\right)
\end{gathered}
$$

The total cost of transportation, if operated by LHVs or HCVs, could then be calculated by including the number of vehicles needed in absolute numbers with above equations to obtain the total cost per relationship and day:

$$
T C=F C_{h}+\left(\frac{\text { Distance }^{\text {Average speed }} \text { sk } / h_{h}}{\text { sver }}\right) * T V C_{h}
$$

The last step in the calculation of the operational cost premises was to apply a logical test through an IFfunction. This function checked whether a condition was met and returned a value reliant on the falseness or trueness of that condition. This function was primarily used to acquire the data of the optimal vehicle type for

\begin{tabular}{|c|c|c|}
\hline & Variables & \\
\hline Fixed costs & Distance-based variable costs & Time-based variable costs \\
\hline Price of procurement & Tires $(\mathrm{SEK} / \mathrm{km})$ & Salary and payroll tax (SEK/hour) \\
\hline Life span & Repair and maintenance $(\mathrm{SEK} / \mathrm{km})$ & Other, i.e. taxes, insurance, \\
\hline Yearly depreciation & Fuel consumption $(\mathrm{L} / \mathrm{km})$ & equipment etc. (SEK/hour) \\
\hline Average tied up capital & Fuel costs $(\mathrm{SEK} / \mathrm{L})$ & \\
\hline Cost of capital & Depreciation (SEK/km) & \\
\hline
\end{tabular}
the optimal scenario. The cost-value of $\mathrm{HCV}$ was returned when the value of the total operational costs for HCV was less than LHV, and the value of LHV was returned if this was false.

Table 2 Variables comprehended in the suggested Cost Benefit Model 


\begin{abstract}
IF (logical_test; value_if_true; value_if_false)
IF $\left(T C_{H C T}<T C_{L H V} ;\right.$ value_if_true_TC $C_{H C T} ;$ value_if false_TC $\left.C_{L H V}\right)$
\end{abstract}

The variables of emissions were presented in $\mathrm{kg} / \mathrm{litre}$ fuel and cost $/ \mathrm{kg}$ emissions and recalculated to cost $/ \mathrm{ve-}$ hicle-km to be applied to each transport by simply being multiplied to the needed number of vehicles and distance.

The first step calculated each emission's total weight for both LHV and HCV. By including variables such as distance between the origin and destination, fuel consumption per $\mathrm{km}$ for each vehicle type, the emission release for a certain oxide per litre and the number of vehicles needed for that particular transport, the released amount of emissions in $\mathrm{kg}$ was obtained.

$$
\begin{aligned}
& \text { Emission }_{X_{k g}}=\left(\left(\text { Distance } \times \text { Fuel consumption }{ }_{L H V / H C V}\right) \times \text { Emission }_{X} k g / l\right) \\
& \times \text { Demand }_{L H V / H C V}
\end{aligned}
$$

The next step calculated the cost for that particular emission and transport. These steps were calculated on each row of data between every relationship and for each particular transport. The result could then be aggregated and presented in different ways, for example, for a certain relationship, a certain weekday, for the whole network or for a designated network alone.

$$
\text { Emissions }_{S E K}=\text { Emission }_{K g} \times \text { Emission }_{X} \text { SEK } / \mathrm{kg}
$$

Road wear could easily be added in the externalities by just multiplying the cost per $\mathrm{km}$ per LHV or HCV with the total vehicle- $\mathrm{km}$. The road wear of an HCT can increase if the maximum weight limit is increased but not the length limit, or even decrease if the maximum length limit is increased but not the weight limit.

Road wear $_{S E K}=\left(\right.$ Road wear SEK $/ k_{L H V_{H C V}} \times$ Distance $) \times$ Demand $_{L H V / H C V}$

Cost of accidents was re-calculated upon the amount of accidents in 2017 with a deduction of the risk valuation cost of, as the reviewed literature suggests, an approximately $50 \%$ reduced risk of accidents in larger vehicles. The Material Cost, Risk Valuation and Cost of Accident for fatal, severe and slight accidents were summed and divided by the total vehicle- $\mathrm{km}$ driven in 2017 of trucks with a minimum gross weight of $3.5 \mathrm{t}$. This data was obtained from Transport Analysis, a Swedish government agency responsible for official statistics in transports. The equation provided an accident cost per vehicle-km.
Calculated accident cost per vehicle- $\mathrm{km}$ and vehicle type was then converted to a total cost for the transport, if operated by HCV or LHV.

$$
\begin{aligned}
\text { Accident cost } \text { sEK }_{\text {S }}= & \left(\text { Accident cost SEK } / \mathrm{km}_{\mathrm{LHV} / H C V} \times \text { Distance }\right) \\
& \times \text { Demand }_{L H V / H C V}
\end{aligned}
$$

At last, the total external cost for each vehicle type was calculated by summing up the total cost of emissions, road wear and accidents.

$$
\begin{aligned}
\text { Total external cost }_{L H V / H C V} & =T C \text { Emissions }_{L H V / H C V} \\
& +T C \text { Roadwear } \\
& + \text { RC Accidents } \text { A }_{L H V / H C V}
\end{aligned}
$$

All variables applied in the model can be found in Additional file 2.

\section{Results}

Following the principles of the suggested cost benefit model, calculations reveal that HCT is not always more suitable and could, in fact, become costly. The resemblance between different fill rates in LHVs and HCVs has been compared. A 100\% fill rate LHV based on loading metres corresponds to a $76 \%$ fill rate in an HCV. It can, therefore, be determined that an $\mathrm{HCV}$ must be filled with more than $75 \%$ to become economically feasible. This has been validated and developed in Table 3 .

However, the general approach in the model is based on the current average fill rate of $75 \%$ in LHVs. According to DHL and previous literature, it is not reasonable to have an average fill rate of $100 \%$ (c.f [26].), as there must be a certain volume available to manage fluctuations and gain some flexibility. The principles and motivations behind the applied fill rates in this particular case are based on the available LDMs in DHL's current operations. The fill rate of $75 \%$ in LDMs is, in an LHV, equal to $15.6 \mathrm{LDM}(20.8 \times 0.75=15.6)$, thus there are 5.2 LDMs still available $(20.8-15.6=5.2)$. It is, therefore, assumed that 5.2 LDMs are needed in an HCV to ensure the same flexibility and to secure extra capacity for fluctuations in demand and variations. In examining the fill rate an HCV would have, if available space must be equal to 5.2 LDMs, an average fill rate of approx. $80 \%$ $((27.3-5.2) / 27.3=0.809)$. Therefore, a fill rate of $80 \%$ was used for the HCT's calculations. Based on this foundation, the model presents a potential cost reduction of $6 \%$ if HCT is introduced. However, the costs increase if HCVs replace LHVs on the full terminal network (see Table 3). The evidence further clarifies the importance of carefully introducing $\mathrm{HCT}$, as it must only be

$$
\text { Accident cost } t_{S E K / k m}=\frac{\left(\left(M C_{F \alpha}+R V_{F \alpha}+C o A_{F \alpha}\right) \times O_{F \alpha}+\left(\left(M C_{S e v}+R V_{S e v}+C o A_{S e v}\right) \times O_{S e v}\right)+\left(M C_{S l i}+R V_{S l i}+C o A_{S l i}\right) \times O_{S l i}\right)}{\text { Total Vehicle km }}
$$


Table 3 Feasible fill rates for converting to HCT

\begin{tabular}{|cc|c|c|c|c|}
\hline \multicolumn{2}{|c|}{ Average Fill Rate } & Scenario A & Scenario B & Scenario C \\
LHV & HCV & (Soley LHV) & (Soley HCV) & $\begin{array}{c}\text { Savings } \\
\text { (Sc A - Sc C) }\end{array}$ \\
\hline $100 \%$ & $75 \%$ & $100 \%$ & $110 \%$ & $100 \%$ & $0 \%$ \\
$100 \%$ & $85 \%$ & $100 \%$ & $108 \%$ & $98 \%$ & $2 \%$ \\
$100 \%$ & $95 \%$ & $100 \%$ & $106 \%$ & $97 \%$ & $3 \%$ \\
$100 \%$ & $100 \%$ & $100 \%$ & $105 \%$ & $97 \%$ & $3 \%$ \\
\hline \hline $75 \%$ & $80 \%$ & $100 \%$ & $102 \%$ & $94 \%$ & $6 \%$ \\
\hline
\end{tabular}

implemented in the appropriate locations and only where it is actually required.

The results of the environmental performance disclose a potential in the environmental performance as well. However, the results here are very interesting, as the potential for solely HCVs to be used in the full terminal network was demonstrated (see Table 4).

If the environmental performance is converted to the financial impact that falls on society, it can be seen that the external costs per type of oxide are reduced. Accidental costs are mostly affected by solely using HCT, as HCVs have much lower risks of being in an accident compared to LHVs (see Table 5).

To conclude, there is potential for HCT, which confirms previous research related to HCT. There are, however, still some negative impacts with HCT, as is illustrated when solely HCVs are used in the terminal network. If HCT is only used when suitable in the transport relationships, the number of transportations can be reduced by almost $10 \%$ of vehicle trips per year. Table 6 illustrates the different outcomes produced by the model. The darkest cells illustrate negative impacts, while lighter cells illustrate positive impacts and reductions in relation to current scenario of solely LHVs in operations. HCT does not result in a positive effect in all 600 relations between the 25 terminals in the system, as showed in Table 6. As the presented data demonstrate that a sole operation of HCVs everywhere is not economically justifiable due to carried volumes, it is logical to assume the potential should be larger in terminals with high volumes. If this is tested by reducing the data in the model of all 25 terminals to only a designated network of the six terminals with the highest volumes, a considerably greater potential is identified. Even when HCVs are solely used in the designated line-haul network of the six largest terminals, the costs will still be reduced due to the large volumes, which supports the assumption of high volumes being a prerequisite to achieve the benefits of HCT.

\subsection{Analysis}

The calculations are only based on the costs of LHVs in comparison to HCVs, and this could be a weakness of the model. For example, even if a smaller vehicle like a van or small truck would be sufficient in practice, the model would still calculate the cost for either an LHV or $\mathrm{HCV}$. Also, if the model calculates a need for $3.15 \mathrm{HCVs}$ in a certain relationship, the output would use $4 \mathrm{HCVs}$ and not 3 HCVs and 1 LHV as would be done in reality. Therefore, in these occasions, the operational costs and environmental effects would be less than the result given by the model, which is considered as a weakness. The costs of handling and coupling operations at the terminals are also excluded in the model, but this should be considered as an important factor when implementing HCT. These activities could be handled by a tugmaster operated by a terminal employee or the truck driver. The coupling will take more time for an HCV than for an LHV; as there are 2 trailers instead of 1 , this will affect the lead times, which could affect the system. The handling cost for HCVs is most likely higher than LHVs. However, as the vehicles are only longer, standardised equipment and chassis across the industry can still be used which reduces the handling time and cost. The

Table 4 Environmental Performance

\begin{tabular}{|l|ccc|cc|}
\cline { 2 - 6 } \multicolumn{1}{c|}{} & $\begin{array}{c}\text { Scenario A } \\
\text { (Soley LHV) }\end{array}$ & $\begin{array}{c}\text { Scenario B } \\
\text { (Soley HCT) }\end{array}$ & $\begin{array}{c}\text { Scenario C } \\
\text { (Optimal Setup) }\end{array}$ & $\begin{array}{c}\text { Differential } \\
\text { (Sc.A - Se.B) }\end{array}$ & $\begin{array}{c}\text { Differential } \\
\text { (Sc.A - Sc.C) }\end{array}$ \\
\hline Fuel (L) & $100 \%$ & $97 \%$ & $93 \%$ & $3 \%$ & $7 \%$ \\
CO$_{2}$ (kg) & $100 \%$ & $97 \%$ & $93 \%$ & $3 \%$ & $7 \%$ \\
Nox (kg) & $100 \%$ & $97 \%$ & $93 \%$ & $3 \%$ & $7 \%$ \\
HC (kg) & $100 \%$ & $96 \%$ & $93 \%$ & $4 \%$ & $7 \%$ \\
PM (kg) $_{\mathbf{S O}_{2}(\mathbf{k g})}^{100 \%}$ & $100 \%$ & $97 \%$ & $93 \%$ & $3 \%$ & $7 \%$ \\
\hline
\end{tabular}


Table 5 External Costs

\begin{tabular}{|l|cc|c|c|c|}
\cline { 2 - 6 } \multicolumn{1}{c|}{} & $\begin{array}{c}\text { Scenario A } \\
\text { (Solely LHV) }\end{array}$ & $\begin{array}{c}\text { Scenario B } \\
\text { (Solely HCT) }\end{array}$ & $\begin{array}{c}\text { Scenario C } \\
\text { (Optimum) }\end{array}$ & $\begin{array}{c}\text { Differential } \\
\text { (Sc A - Sc B) }\end{array}$ & $\begin{array}{c}\text { Differential } \\
\text { (Sc A - Sc C) }\end{array}$ \\
\hline $\mathbf{C O}_{2}$ & $100 \%$ & $97 \%$ & $93 \%$ & $3 \%$ & $7 \%$ \\
NOx & $100 \%$ & $97 \%$ & $93 \%$ & $3 \%$ & $7 \%$ \\
$\mathbf{H C}$ & $100 \%$ & $98 \%$ & $93 \%$ & $2 \%$ & $7 \%$ \\
$\mathbf{P M}$ & $100 \%$ & $96 \%$ & $93 \%$ & $4 \%$ & $7 \%$ \\
SO $_{2}$ & $100 \%$ & $96 \%$ & $93 \%$ & $4 \%$ & $8 \%$ \\
\hline Total Cost (Emissions) & $100 \%$ & $97 \%$ & $93 \%$ & $3 \%$ & $7 \%$ \\
\hline Road Wear Cost & $100 \%$ & $90 \%$ & $93 \%$ & $10 \%$ & $7 \%$ \\
Accident Cost & $100 \%$ & $69 \%$ & $90 \%$ & $31 \%$ & $10 \%$ \\
\hline Total External Costs & $100 \%$ & $85 \%$ & $92 \%$ & $15 \%$ & $8 \%$ \\
\hline
\end{tabular}

management structure, logistics setup and other equipment (e.g. tugmaster) does also affect the time and cost for coupling and handling. Nevertheless, as the number of vehicles is reduced with the increased capacity in HVCs reduces the number of trips required per day given the demand, hence also the number of vehicles that must be handled. The weighed cost can therefore be balanced out or even become an advantage for HCT.

Table 7 and Fig. 2 account for the sensitivity analyses conducted. Table 7 presents how the total costs in the optimal scenario change when different variables are decreased or increased by $10 \%$ and $30 \%$. For example, if the costs regarding fuel increased by $30 \%$, the findings would result in an increase of $9 \%$ in the total costs in the optimal scenario. The variables of fuel, salary, utilised hours and average speed have a significant effect in all scenarios on the total cost. The results demonstrate which variables affect the model the most and what parameters are highly sensitive to changes. The environmental effects would not be affected by price adjustments in different parameters and are, thus, not accounted for in the calculations.

Another aspect that would have some influence on the total cost is the fill rates of the vehicles. The fill rate in the vehicles determines how much of the available LDMs are used for each transport. In the model, the fill rates are based on the total LDMs available, which is equivalent to $20.8 \mathrm{~m}$ in an LHV and $27.3 \mathrm{~m}$ in an HCV. To analyse how the fill rate affects the total cost, a sensitivity analysis was performed exclusively for the fill rates (see Fig. 2). Figure 2 illustrates how different fill rates over the various scenarios affect the total cost when adjusted over the span of $+/-25 \%$ from the destined fill rates of $75 \%$ in an LHV and $80 \%$ in an HCV. When these fill rates are used, both vehicles have an excess capacity of approximately 5.2 LDMs. The findings show that there is more to lose if the fill rate decreases than there is to gain in an increase. If only LHVs are used in the terminal network, a decrease of $25 \%$ of the fill rate would result in a total cost increase of $10 \%$. If the fill rate increased by $25 \%$, the total costs would decrease by $5 \%$. This relation is comparable with the two other scenarios, but the effect here is slightly less extensive. If the fill rates in the optimal scenario increased by $25 \%$, the total cost would decrease by $3 \%$, and if it decreased by $25 \%$, the total cost would increase by $7 \%$.

Based on LDMs, an HCV of $34.5 \mathrm{~m}$ increases the capacity by $31 \%$. Kyster-Hansen and Sjögren [19] roughly

Table 6 Summarised result of an introduction of HCT in a full vs designated network

\begin{tabular}{|c|c|c|c|c|c|}
\hline & \multirow[b]{2}{*}{$\begin{array}{l}\text { Scenario A } \\
\text { Soley LHV }\end{array}$} & \multicolumn{2}{|c|}{ Full Terminal Network } & \multicolumn{2}{|c|}{ Designated Terminal Network } \\
\hline & & $\begin{array}{l}\text { Scenario B } \\
\text { Soley HCT } \\
\end{array}$ & $\begin{array}{c}\text { Scenario C } \\
\text { Optimum }\end{array}$ & $\begin{array}{l}\text { Scenario B } \\
\text { Soley HCT }\end{array}$ & $\begin{array}{c}\text { Scenario C } \\
\text { Optimum }\end{array}$ \\
\hline Total Operational Costs & $100 \%$ & $102 \%$ & $94 \%$ & $86 \%$ & $82 \%$ \\
\hline Fixed Costs & $100 \%$ & $105 \%$ & $94 \%$ & $89 \%$ & $84 \%$ \\
\hline Distance Based Costs & $100 \%$ & $107 \%$ & $94 \%$ & $90 \%$ & $84 \%$ \\
\hline Time Based Costs & $100 \%$ & $92 \%$ & $93 \%$ & $77 \%$ & $78 \%$ \\
\hline Overall Environmental Cost & $100 \%$ & $85 \%$ & $92 \%$ & $71 \%$ & $75 \%$ \\
\hline Emissions & $100 \%$ & $97 \%$ & $93 \%$ & $81 \%$ & $80 \%$ \\
\hline Congestion & $100 \%$ & $123 \%$ & $95 \%$ & $107 \%$ & $94 \%$ \\
\hline External Costs Related to Emissions & $100 \%$ & $97 \%$ & $93 \%$ & $80 \%$ & $79 \%$ \\
\hline External Costs Related to Infras tructure & $100 \%$ & $90 \%$ & $93 \%$ & $76 \%$ & $77 \%$ \\
\hline External Costs Related to Safety & $100 \%$ & $69 \%$ & $90 \%$ & $58 \%$ & $68 \%$ \\
\hline
\end{tabular}


Table 7 Sensitivity Analysis

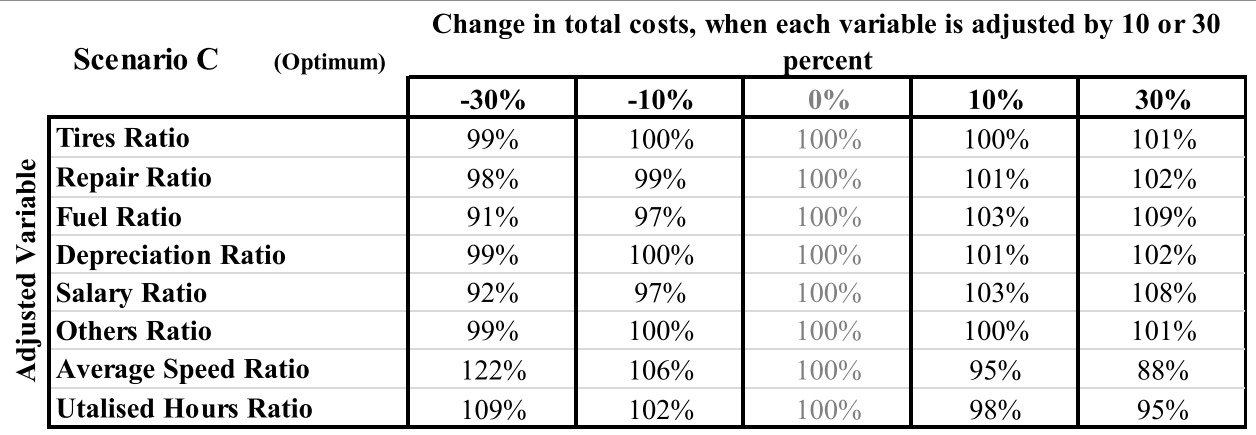

estimated a capacity increase of 50\% to reduce transport costs by $15-20 \%$. This is not supported by the results from this paper or research on line-haul networks that used volume as a constraint, as the calculated costs would only be $6 \%$ with an increase in capacity of $31 \%$. However, the costs are reduced by $18 \%$ if $\mathrm{HCT}$ is only introduced in the relationships between the largest/most beneficial terminals. This also shows that the benefits of HCT are much larger when implemented only where it is truly required, which, in this particular case, would be in the six largest terminals.

The results produced are in line with those from the Swedish Transport Administration [37], which argued for opening up a larger network in southern Sweden for HCT. Results also confirm the prerequisites of large and frequent volumes for feasible HCT. This is illustrated in Fig. 3 where the six largest terminals of DHL are highlighted through darker markings.

Furthermore, better possibilities can be created to achieve economies of scale in the transportation network by consolidating more than one terminal in one freight transport, e.g. by connecting many of the terminals in southern and middle parts of Sweden (see the lighter markings in Fig. 3). To exemplify, if a transport is going from Malmö to Gothenburg, the vehicle will pass Halmstad before continuing towards Gothenburg. For instance, an assumption could be made that there is a demand to transport a trailer from Malmö to Gothenburg as well as a trailer from Halmstad to Gothenburg. A vehicle starting from Malmö with a length of maximum $25.25 \mathrm{~m}$ could then stop by Halmstad and add a second trailer to the equipage. In other words, if there are possibilities to collect an extra trailer, the LHV transforms to an HCV. This would improve the flexibility and decrease the lead time by improving allocation of capacity via dividing and coupling trailers. If there are no such possibilities due to demand in Halmstad, the vehicle just runs as a LHV. This idea can, if setup correctly and carefully, leverage the potential cost savings and also the efficiency of the terminal network from an environmental perspective. This can considerably reduce the costs and increase the quality of the service level. The extra interlink trailers located at

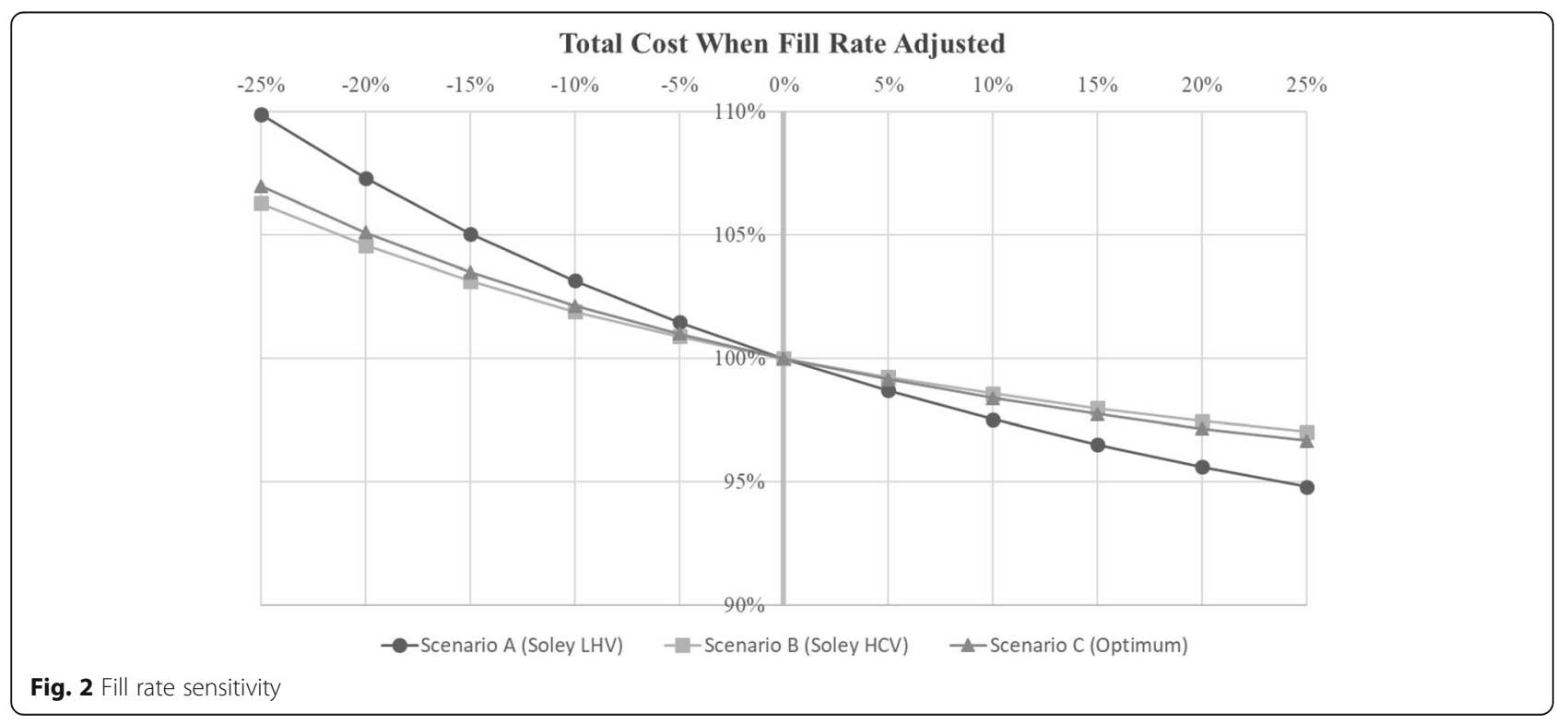




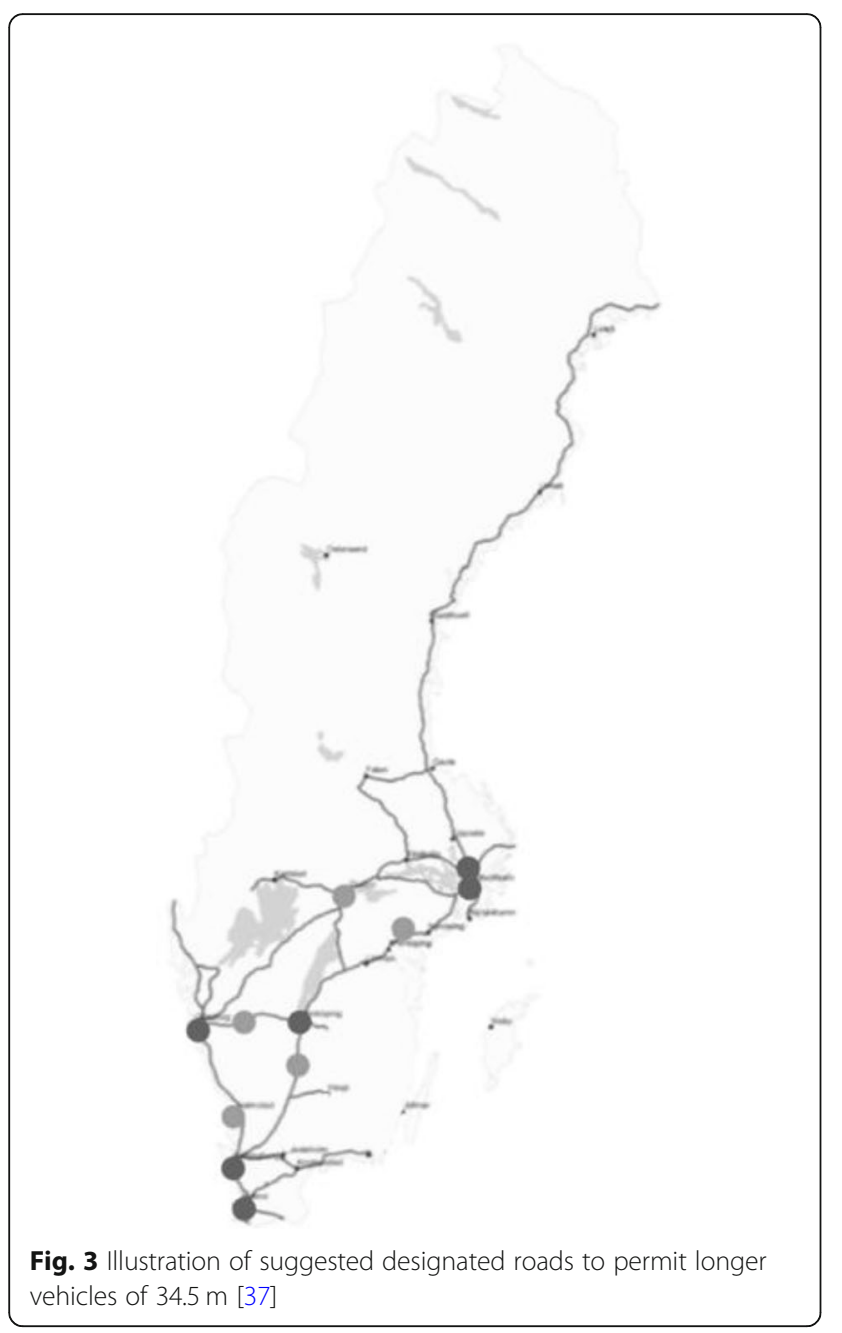

some terminals also have the possibility to be reallocated to handle fluctuations. If the vehicle utilisation of HCVs can be further enlarged from an average of $80 \%$ in fill rate, the number of trips can be reduced even more. By driving past other terminals and consolidating goods, it is not impossible to achieve a fill rate above $80 \%$. However, if Halmstad has a large volume of goods that are to be delivered to Gothenburg, it might still need an extra vehicle; carefulness is, therefore, vital in the planning. This strategy of implementation requires not only carefully performed capacity planning between each of the terminals of interest but also efficient flows of information between the terminals, hauliers and management. A deeper investigation would be required to understand, illustrate and discuss this complexity and its benefits. This appearance and structure are, however, identified and believed to add an extra level of flexibility in the terminal operating network.

HCT is an attractive solution from an environmental perspective, as it is believed to have the potential to minimise total fuel consumption, emissions and traffic congestion [45]. The findings of this report show that this is true, with all types of oxides reduced in the optimal scenario and even in the scenario that solely used HCVs. This is due to the reduced number of vehicles and, as the vehicles are only longer and not heavier, the rise of fuel consumption is only slightly increased (mainly because of different aerodynamics). This also results in a lower load per axle which, consequently, has a reduced tear on the roads and a reduced risk of accidents of HCVs. However, it can be argued that the results showing potential when HCT is solely used are not realistic nor feasible in reality, as there is no financial benefit in this for companies.

\section{Conclusion}

A cost benefit model has been developed to answer the research question and identify the benefits and disadvantages of HCT within a comprehensive line-haul network. The calculations and obtained result have been validated through final expert interviews with DHL Freight among others. The results show great potential with HCT. Furthermore, the model suggests that HCT can be implemented differentiated on designated segments/relations in the line-haul network. The study reveals and presents results that are relevant for the stakeholders and can hence be distinguished as a model applicable in a system analysis.

Based on the calculations made upon DHL's line-haul operations, the model is shown to be sensitive to the parameters of fuel, salary, speed and fill rate. The fill rate moreover reveals that it is vital to keep a high average fill rate, as the effects of the changes on the costs are not linear. This was illustrated when the fill rates were adjusted $+/-25 \%$ of both vehicle types. If the fill rate reduced from $75 \%$ to $56.25 \%$ in the LHVs, and from $80 \%$ to $60 \%$ in the HCVs, the costs would increase by $7 \%$. However, if the fill rate increased from $75 \%$ to $93.75 \%$ in the LHVs, and from $80 \%$ to $100 \%$ in the HCVs, the costs would reduce by $3 \%$. It also indicates that an external factor such as an economic recession could have a large effect on the usage of HCVs. Nevertheless, HCT has the possibility to reduce operational costs, improve environmental performance and, consequently, reduce the external costs. However, a prerequisite is that large volumes exist and remain frequent with little to no variation. This is further illustrated in Table 6, which presents a capability of reducing external costs by $8 \%$ if HCT is introduced in the full network. If many relations that do not have large volumes to transport are excluded, the external costs can be reduced by $15 \%$.

In relation to limitations, the model does not take into consideration any costs of handling, coupling and such in terminals nor an optimal driving route for consolidations between different terminals. The model does not have any route planner algorithm and is dependable on 
good quality of input data. The main argument for not including these types of costs is that it brings a level of detail to the model that is very hard to validate since there is no real work experiments and cases to study in order to get the proper quality of input data. Nevertheless, it is possible to further develop the analysis by including costs for the congestion and used space, terminal handling costs based on coupling and decoupling and by including the external costs for noise emissions, as more demonstrations are available. Future research could also focus on intermodality and its possible connection to HCT.

\section{Supplementary Information}

Supplementary information accompanies this paper at https://doi.org/10 1186/s12544-020-00451-5.

Additional file 1. Literature Review.

Additional file 2. External Costs (SEK).

\section{Acknowledgements}

We thank DHL Freight Sweden for its data sharing and for the assistance in the research of High Capacity Transport by validating variables and fixed costs that are directly related to road transportation.

\section{Authors' contributions}

DL and MS have made equally substantial contributions to the conception of the work. RB has contributed with experience and guidance throughout the paper, HCT tests and other vital information for the analysis of previous research. The author(s) read and approved the final manuscript.

\section{Funding}

This research was further supported by specific funding from the Swedish Transport Agency (Grant No: 2019/89470). Open Access funding provided by Gothenburg University Library.

\section{Availability of data and materials}

The datasets generated and analysed during the current study are not publicly available due to confidentiality but are available from the corresponding author on reasonable request and with permission from $\mathrm{DHL}$.

\section{Competing interests}

The authors declare that they have no competing interests.

Received: 29 November 2019 Accepted: 20 October 2020

Published online: 04 November 2020

\section{References}

1. Pålsson, H., Winslott Hiselius, L., Wandel, S., Khan, J., \& Adell, E. (2017). Longer and heavier road freight vehicles in Sweden: Effects on tonne-and vehicle-kilometres, CO2 and socio-economics. International Journal of Physical Distribution and Logistics Management, 47(7), 603-622.

2. Swedish Environmental Protection Agency, (2018a), National Inventory Report Sweden, greenhouse gas emission inventories 1990-2016. United Nations Framework Convention on Climate Change and the Kyoto Protocol.

3. Government Offices of Sweden. (2017). The climate policy framework https://www.government.se/articles/2017/06/the-climate-policy-framework/ [Accessed 27 Feb 2019].

4. Swedish Environmental Protection Agency. (2018b). Fördjupad analys av svensk klimatstatistik 2018, Swedish Environmental Protection Agency, Rapport 6848.

5. Meers, D., van Lier, T., \& Macharis, C. (2018). Longer and heavier vehicles in Belgium: A threat for the intermodal sector? Transportation Research Part D: Transport and Environment, 61, 459-470.
6. Knight, I., Newton, W., Barlow, T., McCrae, I., Dodd, M., Couper, G., Ramdas, V. (2008). Longer and/or longer and heavier goods vehicles (LHVs): A study of the likely effects if permitted in the UK (no. PPR 285). UK: TRL.

7. Åsman, P., \& Asp, T. (2018). Annual report of high capacity transport 2017 Gothenburg: The Swedish Transport Administration.

8. Christidis, P., \& Leduc, G. (2009). Longer and heavier vehicles for freight transport, (pp. 1-40). Luxembourg: JRC European Commission.

9. Vierth, I., Berell, H., McDaniel, J., Haraldsson, M., Hammarström, U., Yahya, M. R.,... Björketun, U. (2008). The effects of long and heavy trucks on the transport system: Report on a government assignment. Linköping: Statens väg-och transportforskningsinstitut.

10. De Ceuster, G., Breemersch, T., Van Herbruggen, B., Verweij, K., Davydenko, I., Klingender, M., ... and Bereni, M. (2008). Effects of adapting the rules on weights and dimensions of heavy commercial vehicles as established within directive 96/53/EC.

11. Leach, D. Z., \& Savage, C. J. (2012). Impact assessment: High capacity vehicles.

12. McKinnon, A. (2016). Freight transport in a low-carbon world: Assessing opportunities for cutting emissions. TR News, (306).

13. Korzhenevych, A., Dehnen, N., Bröcker, J., Holtkamp, M., Meier, H., Gibson, G., Cox, V. (2014). Update of the handbook on external costs of transport. London: European Commission DG MOVE.

14. Bálint, A., Fagerlind, H., Martinsson, J., \& Holmqvist, K. (2014). Accident analysis for traffic safety aspects of high capacity transports.

15. Castillo-Manzano, J. I., Castro-Nuño, M., \& Fageda, X. (2016). Exploring the relationship between truck load capacity and traffic accidents in the European Union. Transportation research part E: logistics and transportation review, 88, 94-109.

16. Hassall, K. (2014). Quantifying the benefits of high productivity vehicles (no. APR465/14).

17. Montufar, J., Regehr, J., Rempel, G., \& McGregor, R. V. (2007). Long combination vehicle (LCV) safety performance in Alberta: 1999-2005. Calgary: Montufar and Associates Transportation Consulting.

18. Wăhlberg, A. E. (2008). Meta-analysis of the difference in accident risk between long and short truck configurations. Journal of Risk Research, 11(3), 315-333.

19. Kyster-Hansen, H., \& Sjögren, J. (2013). Roadmap high capacity transports on road in Sweden. In Forum for innovation in the transport sector, Lindholmen Science Park, Gothenburg.

20. Andersson, J., Renner, L., Sandin, J., Fors, C., Strand, N., Hjort, M., ... Almqvist, S. (2011). Trafiksäkerhetspåverkan vid omkörning av 30-metersfordon. Linköping: Statens väg-och transportforskningsinstitut.

21. Kulcsar, B., (2017). SAEFFLOW - Safety and efficiency analysis of HCT-traffic flow indicators. Rapport för FFI-projekt 2014-03933, 2017.

22. Natanaelsson, K., Åsman, P., Grudemo, S., \& Adell, E. (2015). Rapport Systemanalys av införande av HCT på väg Slutversion - Underlagsrapport till regeringsuppdraget "Fördjupade analyser av att tillåta tyngre fordon på det allmänna vägnätet" (Rapport 2015:234). Borlänge: Trafikverket.

23. Ericson, J., Lindberg, G., Mellin, A., \& Vierth, I. (2010). Comodality-The socio-economic effects of longer and/or heavier vehicles for land-based freight transport. In Proceedings of the 12th WCTR, Lisbon, Portugal, (pp. 11-15)

24. Cider, L., and Ranäng, S. (2013). Slutrapport Duo2-Trailer. FFI (Fordonsstrategisk Forskning och Innovation)

25. Löfroth, C., Larsson, L., Enström, J., Cider, L., Svenson, G., Aurell, J., ... Asp, T. (2012). ETT-a modular system for forest transport. In HVTT12: 12th international symposium on heavy vehicle transport technology.

26. Kohn, C. (2005). Centralisation of distribution systems and its environmental effects (doctoral dissertation, Ekonomiska institutionen).

27. McKinnon, A. C. (2012b). Reducing energy consumption and emissions in the logistics sector. In Energy, transport, and the environment, (pp. 521-537). London: Springer.

28. Löfroth, C., and Svenson, G. (2012). ETT-Modulsystem för skogstransporter-En trave Till (ETT) och Större Travar (ST). Arbetsrapport från Skogforsk 758. $158 \mathrm{~s}$.

29. Adell, E., Ljungberg, C., Börefelt, A., \& Hanander, M. (2013). 1-årsutvärdering av projektet ETT coil till (ECT). Trivector, report PM, (vol. 37).

30. Bergqvist, R., \& Monios, J. (2016). The last mile, inbound logistics and intermodal high capacity transport-the case of Jula in Sweden. World Review of Intermodal Transportation Research, 6(1), 74-92.

31. Transport and Environment (2013), "Longer and heavier lorries in the EU", Available at: https://www.transportenvironment.org/sites/te/files/ 
publications/T\%26E\%20position\%20paper\%20megatrucks\%202013_final.pdf [Accessed 28 Feb 2019].

32. Vierth, I., Lindgren, S., \& Lindgren, H. (2018). Impact of higher road vehicle dimensions on modal split: An ex-post analysis for Sweden. Linköping: Statens väg-och transportforskningsinstitut.

33. Bergqvist, R., \& Behrends, S. (2011). Assessing the effects of longer vehicles: The case of pre-and post-haulage in intermodal transport chains. Transport Reviews, 31(5), 591-602.

34. Rodrigues, V. S., Piecyk, M., Mason, R., \& Boenders, T. (2015). The longer and heavier vehicle debate: A review of empirical evidence from Germany. Transportation Research Part D: Transport and Environment, 40, 114-131.

35. Rushton, A., Croucher, P., \& Baker, P. (2014). The handbook of logistics and distribution management: Understanding the supply chain. London: Kogan Page Publishers.

36. DHL, Deklaration av emissionsberäkning, 2018. https://www.logistics.dhl/ content/dam/dhl/local/se/dhl-freight/documents/pdf/se-freightemissionsdeclaration-se.pdf. Accessed 9 Feb 2019.

37. Natanaelsson, K., \& Brandt, J. (2019). Längre lastbilar på det svenska vägnätet - För mer hållbara transporter. (2019:076). Borlänge: Trafikverket.

38. DHL, 2020, Platser DHL-Freight, https://www.dhl.com/se-sv/home/varadivisioner/frakt/kundservice/fraktterminaler-och-platser.html. Accessed 27 Feb 2019.

39. Flodén, J. (2007). Modelling intermodal freight transport. The Potential of Combined Transport in Sweden. Gothenburg: Department of Business Administration Företagsekonomiska institutionen.

40. Asmoarp, V., Jonsson, R., and Funck, J. (2015). Monitoring fuel consumption of a 74-tonne chip truck in the ETT project. Skogforsk.

41. Adell, E., Khan, J., Hiselius, L., Lund, E., Nelldal, B. L., Pettersson, F., ... Wandel, S. (2016). Systemanalys av införande av HCT på väg i Sverige. Environmental and Energy Systems Studies. Lund: Miljö-och energisystem, LTH, Lunds universitet.

42. Johansson, F., von Hofsten, H. (2017). HCT-kalkyl - an interactive cost calculation model for comparing trucks of different sizes. Skogforsk.

43. Swedish Transport Administration (2018). Analysmetod och samhällsekonomiska kalkylvärden för transportsektorn: ASEK 6.1. https:// www.trafikverket.se/contentassets/4b1c1005597d47bda386d81dd3444b24/ asek-6.1/asek_6_1_hela_rapporten_180412.pdf [Accessed 2 Apr 2019].

44. Statistics Sweden, (2019). Statistics Database. http://www.scb.se/ [Accessed 05 Feb 2019].

45. Kharrazi, S., Aurell, J., Sadeghi Kati, M., Jacobson, B., Fröjd, N., \& Asp, T. (2014). Towards performance based standards in Sweden. In 13th international heavy vehicle transport technology symposium, San Luis, Argentina, 2014.

\section{Publisher's Note}

Springer Nature remains neutral with regard to jurisdictional claims in published maps and institutional affiliations.

\section{Submit your manuscript to a SpringerOpen ${ }^{\circ}$ journal and benefit from:}

- Convenient online submission

- Rigorous peer review

- Open access: articles freely available online

- High visibility within the field

- Retaining the copyright to your article

Submit your next manuscript at $\boldsymbol{\nabla}$ springeropen.com 